\title{
Histomorphometric evaluation of the effects of local application of red cloveroil (trifolium pratense) on bone healing in rats \\ Nada M.H. AL-Ghaban ${ }^{(1)}$, Ghazwan H. Jasem ${ }^{(2)}$ \\ Article DOI: https://doi.org/10.26477/jbcd.v32i2.2891
}

\begin{abstract}
Background: Red clover oil (Trifolium pratense) has isoflavones bunches which have estrogen-like exercises and may establish an option in contrast to hormone substitution treatment. The present study investigated the impact of Red clover oil on bone healing in rats by histomorphometric study.

Materials and Methods: Intra bony defect was performed in right femur of thirty six healthy male albino rats. Then these rats were randomly divided into three groups (12 rats each): one control and 2 experimental groups. For control, the bony defect was left for normal healing; for the experimental (S) group, the defect was treated with hemostatic absorbable gelatin sponge; and for experimental (RS) group, the bony defect was treated with $0.2 \mathrm{ml}$ red clover oil and covered by haemostatic absorbable gelatin sponge. Six rats from each group were sacrificed at 2 and 4 weeks intervals. Histomorphometric analysis was performed on H\&E bone section of all the studied groups which includes counting of bone cells (osteoblasts, osteocytes and osteoclasts), trabecular number, trabecular area and bone marrow space area.

Results: Histomorphometric results of bone cells revealed that the combination group stimulated larger numbers of osteoblasts and osteocytes than in sponge and control group. Number of new bone trabeculae, trabecular area and bone marrow space area showed higher mean values in combination groups than others. Highly significant differences between groups were observed in all histomorphometric parameters throughout all durations.

Conclusion: Red clover oil stimulated larger numbers of osteoblasts and osteoclasts, indicating increased bone remodeling especially at 2 weeks interval as compared with sponge and control groups.
\end{abstract}

Key words: Bone defect, Red clover, Rats. (Received:15/8/2019; Accepted:24/9/2019)

\section{INTRODUCTION}

Bone mending is a profoundly effective procedure that takes into account the scar less recovery and redesigning of imperfections identified with the treatment of injury, pathology, or inborn variations from the norm. Bone fix was a multistep procedure including relocation, expansion, separation, and initiation of a few cell types. ${ }^{(1)}$ Bone redesigning requires the relations between numerous bone cells to revamp, protect, or direct bone quality or potentially mineral homeostasis in the light of adjusting natural impacts. There were four discrete stages to this procedure: initiation, retention, inversion, and development with ingestion; that occurs through osteoclasts and osteoblasts, correspondingly. ${ }^{(2)} \quad$ Bone imperfections attempt accommodating recuperating strategy through synchronized accompanying advancement of skeletal and vascular segments in a delicate cartilage callus setting. Among this setting,

(1) Professor, Department of Oral Diagnosis, College of Dentistry, University of Baghdad.

(2) Master Student, Department of Oral Diagnosis, College of Dentistry, University of Baghdad.

Corresponding email, nada_gaban@yahoo.com bone restoration restates a few of the equivalent cell and sub-atomic systems that delivers the embryonic bone. ${ }^{(3)}$

Red clover (Trifolium falsification) is a perpetual herb developing in all mild and subtropical zones in the world over. In a few societies, it is utilized as customary prescription, other than its daidzein and genistein content, red clover shows a high substance of methylized forerunners: biochanin $\mathrm{A}$ and formononetin. ${ }^{(4,5)}$ Isoflavonoids mixes present in red clover oil are the primary dynamic substances of "phytoestrogens". Epidemiological and clinical research revealed constructive outcomes of isoflavone utilization over bone with the danger of building up a few osteoporosis. ${ }^{(6)}$ This study aims to examine the impact of Red clover oil on bone healing in rats histomorphometrically.

\section{MATERIAL AND METHODS:}

Thirty six males healthy albino rats, aged between (4-5) months with weight ranged between (250-300 $\mathrm{mg}$ ), were used in this experimental study. All rats were kept under supervision and nursing from the staff of the animal house of Biotechnology Research 
Center/University of Al-Nahrain, Baghdad, Iraq.

All experimental procedures were conducted in accordance with the ethical approval of animal experiments of College of Dentistry, University of Baghdad. Intra bony defect of about $2 \mathrm{~mm}$ in width and $3 \mathrm{~mm}$ in depth was performed in right femur of each rat. ${ }^{(7)}$ Then rats were randomly divided into three groups (12 rats each):

1) Control group (C): the bonydefect was left for spontaneous normal healing.

2) Experimental group(S): the bony defect was treated with hemostatic absorbable gelatin sponge.

3) Experimental group (RS): the bony defect was treated with $0.2 \mathrm{ml}^{(8)}$ red clover oil (Trifolium pratense) and covered by haemostatic absorbable gelatin sponge.

Then six rats from each group were sacrificed at the end of recommended periods ( 2 and 4 weeks). The right femur was dissected and the soft tissue was removed to expose the entire bone to be cut at $5 \mathrm{~mm}$ away of the defect sides. The bone specimens immediately were stored in $10 \%$ freshly prepared formalin and left for 2 days for fixation. Bone decalcification was performed by using formic acid sodium citrate solution, which was prepared freshly from 2 solutions (125 cc formic acid 90\%, 125 cc distilled water and $50 \mathrm{mg}$ sodium citrate, $250 \mathrm{cc}$ distilled water). ${ }^{(9,10)}$

Then, bone tissue was dehydrated with alcohol and embedded in paraffin. Sections of $5 \mu \mathrm{m}$ were prepared in the usual fashion, and stained with hematoxylin and eosin. Histological examination was performed using light microscope. Histomorphometric assessment of bone cells (osteoblast, osteocyte and osteoclast), trabecular area, trabecular numbers and bone marrow space area was performed by software program (Image J. exe), which is an image processing program developed at the National Institutes of Health. ${ }^{(11)}$

\section{RESULTS \\ Histological results}

A- Control group: Histological view of bone defect revealed sparse of bone trabecular coalesce with cutting bone in control group of 2 weeks duration. Osteocytes in newly formed trabecular enclosing areas of marrow tissue and large number of osteocytes are embedded in bone (fig.1). At 4 weeks duration, the osteoblasts were noticed at peripheries of the thick bone trabecular and osteocytes inside these bone (fig.2).

B- Sponge group (S): The histological examination of this group after 2 weeks duration illustrated the deposition of bone trabeculae that replaces areas of bone defect (fig.3). At 4 weeks, the osteoblasts are seen at peripheries of the bone, osteocytes seen arranged in circular around Haversian canal (fig.4).

C- Combined red clover oil and sponge group (RS): Histological examination of this group after 2 weeks revealed thick well developed bone trabeculae filled defect area with numerous blood vessels and inflammatory cells inside bone marrow (fig.5). At 4 weeks mature bone filled defect area by presence of osteon (fig.6).

\section{Statistical analysis of histomorphometric findings}

Tables (1 and 2) show comparison differences using ANOVA and LSD test among all studied groups at different healing periods for bone parameters trabecular area (BTA), trabecular number (TN) and bone marrow area (BMA) in control(C), sponge (S) and combination (RS) groups in both healing periods ( 2 and 4 weeks). The result showed a highly significant difference between all groups in both durations (two and four weeks) for these three bone parameters. 


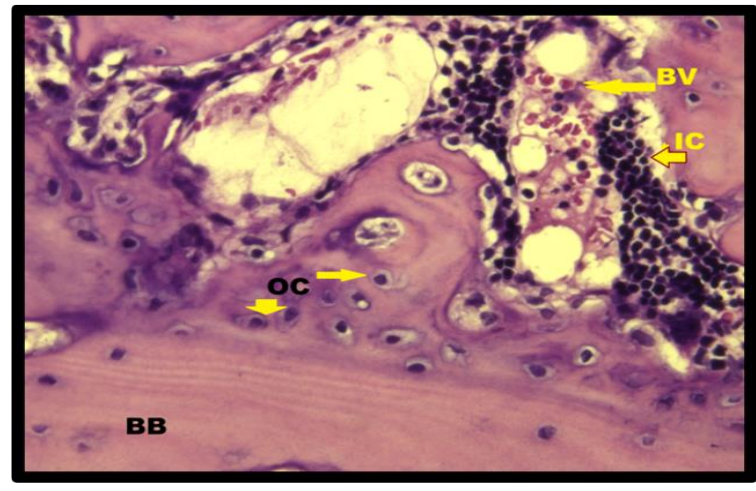

Figure (1): Control group at 2-weeks showing basal bone (BB), blood vessels (BV), inflammatory cells (IC) and osteocvtes (OC). H\&EX40

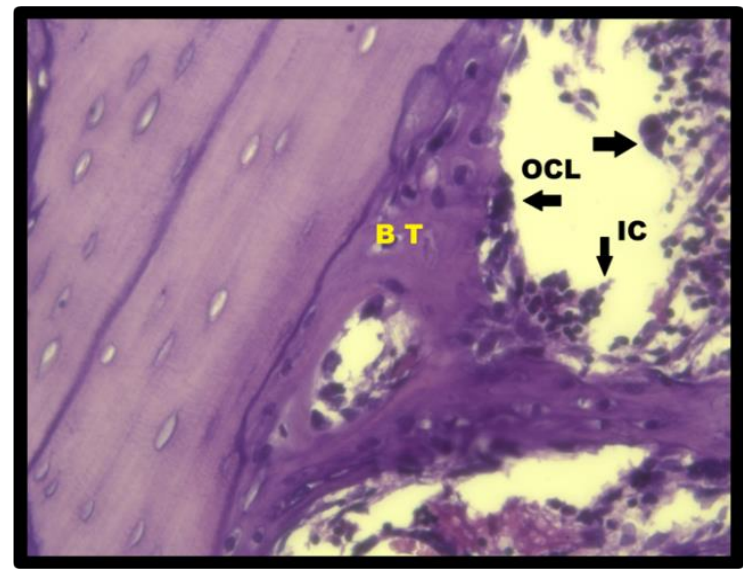

Figure (3): Sponge group at 2-weeks showing new bone trabeculae (BT), osteoclasts (OCL) and inflammatory cells (IC). H\&E X40.

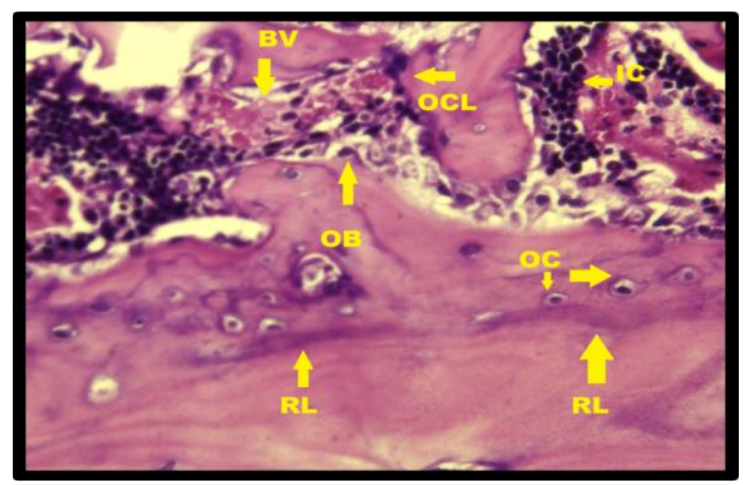

Figure (5): RS group at 2-weeks showing new bone filled by osteocytes (OC) lined by osteoblasts (OB), blood vessels (BV), inflammatory cells (IC), osteoclasts (OCL) and reversal line (RL). H\&EX40

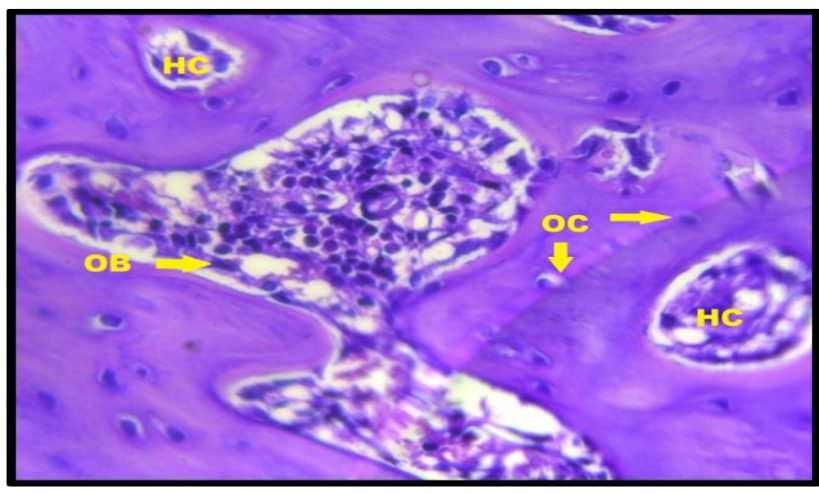

Figure (2): Control group at 4-weeks showing osteoblasts (OB) lined Haversian canal and osteocytes (OC) filled bone. H\&E X40

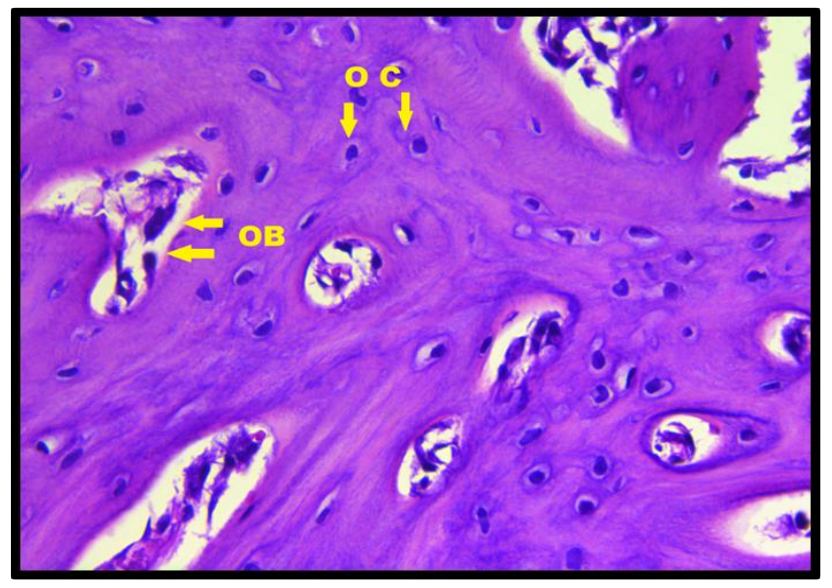

Figure (4): Sponge group at 4-weeks showing regular arrangement of osteocytes (OC) around Haveresian canal (HC) and osteoblasts (OB). H\&EX40

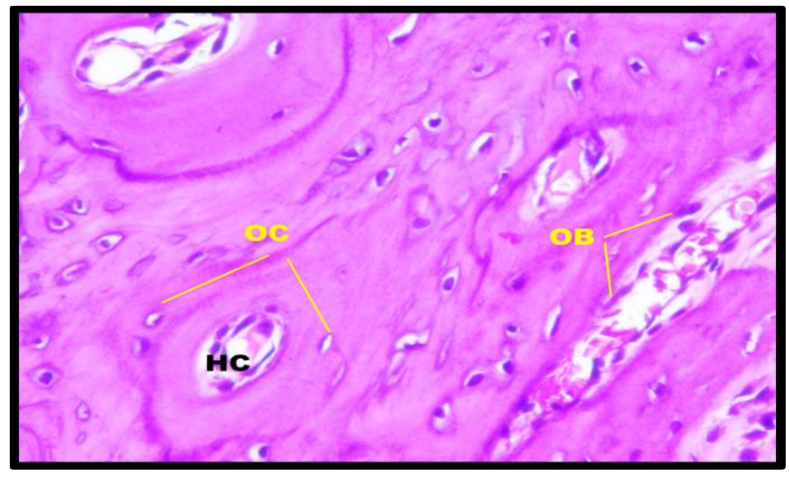

Figure (6 ): RS group at 4-weeks showing mature bone (osteon formation) by regularly arranged osteocytes (OC) around Haversian canal (HC) and Osteoblasts (OB) seen riming haversian canal (HC). H\&EX40 
Table 1: ANOVA group comparisons for bone parameters.

\begin{tabular}{|l|l|l|l|}
\hline Variable & Duration & \multicolumn{2}{|l|}{ Group comparisons } \\
\cline { 3 - 4 } & & F -test & p- value \\
\hline \multirow{3}{*}{ BTA } & 2 weeks & 33.5 & 0.0003 \\
\cline { 2 - 4 } & 4 weeks & 42.9 & 0.0005 \\
\hline TA & 2 weeks & 29.4 & 0.0002 \\
\cline { 2 - 4 } & 4 weeks & 19.7 & 0.0001 \\
\hline \multirow{3}{*}{ BMA } & 2 weeks & 52.3 & 0.0006 \\
\cline { 2 - 4 } & 4 weeks & 112.7 & 0.00008 \\
\hline
\end{tabular}

Table.2: LSD Group Differences in Bone Parameters

\begin{tabular}{|c|c|c|c|c|c|}
\hline \multirow[b]{2}{*}{$\begin{array}{l}\text { Vari } \\
\text { ables }\end{array}$} & \multirow{2}{*}{$\begin{array}{l}\text { Duratio } \\
\text { n }\end{array}$} & \multirow{2}{*}{ Groups } & \multicolumn{3}{|c|}{ Comparisons } \\
\hline & & & M.D. & $\begin{array}{l}\text { p- } \\
\text { value }\end{array}$ & Sig \\
\hline \multirow{6}{*}{ BTA } & \multirow{3}{*}{2 weeks } & $\mathrm{C} / \mathrm{S}$ & -3.8 & 0.0002 & HS \\
\hline & & $\mathrm{C} / \mathrm{RS}$ & -3.0 & 0.001 & HS \\
\hline & & S / RS & -4.4 & 0.0004 & HS \\
\hline & \multirow[t]{3}{*}{4 weeks } & $\mathrm{C} / \mathrm{S}$ & -9.5 & 0.001 & HS \\
\hline & & C/ RS & -7.4 & 0.0001 & HS \\
\hline & & S / RS & -4.9 & 0.003 & HS \\
\hline \multirow[t]{6}{*}{ TA } & \multirow{3}{*}{2 weeks } & $\mathrm{C} / \mathrm{S}$ & -5.6 & 0.006 & HS \\
\hline & & $\mathrm{C} / \mathrm{RS}$ & -8.2 & 0.0011 & HS \\
\hline & & S / RS & 3.2 & 0.0041 & HS \\
\hline & \multirow{3}{*}{4 weeks } & $\mathrm{C} / \mathrm{S}$ & 1.7 & 0.0001 & HS \\
\hline & & $\mathrm{C} / \mathrm{RS}$ & 2.2 & 0.0021 & HS \\
\hline & & S / RS & 2.0 & 0.0087 & HS \\
\hline \multirow{6}{*}{ BMA } & \multirow{3}{*}{$\begin{array}{c}2 \\
\text { weeks }\end{array}$} & $\mathrm{C} / \mathrm{S}$ & 0.737 & 0.0043 & HS \\
\hline & & $\mathrm{C} / \mathrm{RS}$ & 0.654 & 0.0062 & HS \\
\hline & & S / RS & 0.587 & 0.0028 & HS \\
\hline & \multirow{3}{*}{4 weeks } & $\mathrm{C} / \mathrm{S}$ & 0.231 & 0.007 & HS \\
\hline & & C / RS & 0.311 & 0.0028 & $\mathbf{H S}$ \\
\hline & & S / RS & 0.259 & 0.0091 & HS \\
\hline
\end{tabular}

According to the ANOVA test, there was a highly significant difference among all studied groups in both 2 and 4 weeks intervals in bone cells except for osteoclasts at 4 weeks duration which was significant as shown in table (3).

Table 3: LSD group differences in bone cells.

\begin{tabular}{|c|c|c|c|c|c|}
\hline \multirow{2}{*}{$\begin{array}{l}\text { Variable } \\
\text { S }\end{array}$} & \multirow{2}{*}{$\begin{array}{l}\text { Dura } \\
\text {-tion }\end{array}$} & \multirow{2}{*}{$\begin{array}{l}\text { Gro } \\
\text { ups }\end{array}$} & \multicolumn{3}{|c|}{ Comparisons } \\
\hline & & & M.D & P-value & Sig. \\
\hline \multirow{6}{*}{$\begin{array}{l}\text { Osteobla } \\
\text { st }\end{array}$} & \multirow{3}{*}{$\begin{array}{l}2 \\
\text { week }\end{array}$} & $\mathrm{C} / \mathrm{S}$ & -10.4 & 0.003 & HS \\
\hline & & $\begin{array}{l}\mathrm{C} / \\
\mathrm{RS}\end{array}$ & -11.8 & 0.0091 & HS \\
\hline & & $\begin{array}{l}\text { S I } \\
\text { RS }\end{array}$ & $-\overline{11.03}$ & 0.0075 & HS \\
\hline & \multirow{3}{*}{$\begin{array}{l}4 \\
\text { week }\end{array}$} & $\mathrm{C} / \mathrm{S}$ & -6.8 & 0.0013 & HS \\
\hline & & $\begin{array}{l}\text { C I } \\
\text { RS }\end{array}$ & -7.0 & 0.0011 & HS \\
\hline & & $\begin{array}{l}\text { S I } \\
\text { RS }\end{array}$ & -6.92 & 0.004 & HS \\
\hline \multirow{6}{*}{$\begin{array}{l}\text { Osteocla } \\
\text { sts }\end{array}$} & \multirow{3}{*}{$\begin{array}{l}2 \\
\text { week }\end{array}$} & $\mathrm{C} / \mathrm{S}$ & -0.10 & 0.006 & HS \\
\hline & & $\begin{array}{l}\text { C I } \\
\text { RS }\end{array}$ & $\overline{-}$ & 0.0002 & HS \\
\hline & & $\begin{array}{l}\text { S I } \\
\text { RS }\end{array}$ & -0.11 & 0.0016 & HS \\
\hline & \multirow{3}{*}{$\begin{array}{l}4 \\
\text { week }\end{array}$} & $\mathrm{C} / \mathrm{S}$ & -0.24 & 0.0023 & HS \\
\hline & & $\begin{array}{l}\mathrm{C} \\
/ \mathrm{RS}\end{array}$ & -0.29 & 0.02 & $\mathbf{S}$ \\
\hline & & $\begin{array}{l}\text { S I } \\
\text { RS }\end{array}$ & -0.26 & 0.0064 & HS \\
\hline \multirow{6}{*}{$\begin{array}{l}\text { Osteocyt } \\
\text { es }\end{array}$} & \multirow{3}{*}{$\begin{array}{l}2 \\
\text { week }\end{array}$} & $\mathrm{C} / \mathrm{S}$ & 3.8 & 0.0019 & HS \\
\hline & & $\begin{array}{l}\mathrm{C} \\
/ \mathrm{RS}\end{array}$ & 4.4 & 0.0055 & HS \\
\hline & & $\begin{array}{l}\text { S I } \\
\text { RS }\end{array}$ & 4.1 & 0.0028 & HS \\
\hline & \multirow{3}{*}{$\begin{array}{l}4 \\
\text { week }\end{array}$} & $\mathrm{C} / \mathrm{S}$ & -9.7 & 0.0017 & HS \\
\hline & & $\begin{array}{l}\text { C/ } \\
\text { RS }\end{array}$ & -10.4 & 0.0059 & HS \\
\hline & & $\begin{array}{l}\text { S I } \\
\text { RS }\end{array}$ & -10.1 & 0.0094 & HS \\
\hline
\end{tabular}

\section{DISSCUSION}

Within the last decade the use of natural supplements has become more widespread in the search for viable alternatives to existing treatments. Red clover (Trifolium pratense) is a medicinal herb containing flavonoids and isoflavones. Red clover contains at least 9 isoflavones including formononetin, biochanin a (glycosides), daidzein and genistein (aglycones) which promote the formation of 
bone. ${ }^{(12)}$ Cellular processes stimulated include chemotaxis, mesenchymal cell proliferation and differentiation, angiogenesis, and synthesis of extracellular matrix, although different isoflavones compounds are closely related structurally and functionally. ${ }^{(13)}$

Portrayal of the recovered bone tissue is regularly performed by histological assessment with light microscopy, following standard recoloring of the example. Enlightening histology is utilized to give a general appraisal of the tissue of enthusiasm, giving information with respect to cell morphology, structure and course of action inside the interface with the extracellular grid or with an embedded material. ${ }^{(14)}$ In red clover oil and sponge group (GS) treated defect area showed more and thicker bone trabeculae than that of other groups. It has been reported that isoflavones compounds could increase the osteogenic effect by increasing the osteoblast cell proliferation and stimulating matrix activity. (15)

A previous study ${ }^{(16)}$ has been performed to evaluate the performance of isoflavones compounds as a scaffold in bone regeneration procedures to be a promoter of osteoblastic formation and is readily resorbed by osteoclasts. Direct bone matrix anchorage has been shown with collagen fibers deposited in the micropores. Resorption of isoflavones compounds has been reported in a rabbit model with cells having a characteristic of osteoclast cells activity. Histomorphometry permits quantitative examination of histological information, to be specific with respect to length and separation, territory and number of the segments of intrigue. ${ }^{(17)}$

Mean values of trabecular area and number recorded in this study were higher in combination with ( RS ) group, more clearly observed in 4 weeks duration which may seem to be in line with histomorphometric results of Ochiuto et al., $200{ }^{(18)}$ who stated that the increase in osteogenesis seen during the transition from the 14 to 30 days of observation and the total areas of the newly created bone trabeculae showed that the groups submitted to bone filling biomaterial (osteoconduction and autogenous bone graft) showed bone trabeculate area values higher than the control group of the same animal.

The present study revealed that the number of osteoblasts was highest in combination (RS) group when compared to others especially in 2 weeks interval. The number of osteocytes increases with time in all studied groups especially in combination group at 4 weeks interval. These results could be explained by the direct action of red clover oil on the differentiation and maturation of osteoblasts and accelerating rate of matrix deposition and its corresponding calcification. These findings agree with Bharathi \& Baby, $2017^{(19)}$; they found that isoflavones compounds could increase the rate of bone ossification. It is thought to affect bone metabolism by promoting the proliferation of osteoblasts and the synthesis of osteon, which leads to the inhibition of the differentiation of osteoclastlike cells.

\section{CONCLUSION}

Red clover oil is osteoinductive herbal material that promotes and accelerates bone healing process by an early bone formation and maturation. Histmorphometric parameters for all groups showed highly significant difference in overall indicators of bone micro architectures which include trabecular area, trabecular number, bone marrow space area, osteoblasts, and osteocytes numbers.

\section{Conflict of interest: None.}

\section{REFERENCES:}

1. Short AR, Koralla D, Deshmukh A, Wissel B, Stocker B, Calhoun M, et, al. Hydrogels that allow and facilitate bone repair, remodeling, and regeneration.J.Mater.Chem.2015;3(40):7818-30.

2. Grosland NM, Goel VK, Lakes RS. Techniques and applications of adaptive bone remodeling concepts. J.Biomech.Res.2019;4:53-75.

3. Winkler T, Sass FA, Duda GN, Schmid-Bleek K. A review of biomaterials in bone defect healing, remaining shortcomings and future opportunities for bone tissue engineering: The unsolved challenge. BJR.2018;7(3):232-243.

4. Lall S. Evaluation of the therapeutic potential of red clover extract and red grape seed extract on human adult malignant brain tumours in vitro. $\mathrm{PhD}$ thesis, Mideast University,2017.

5. Watanabe S, \& Uehara M.Health Effects and Safety of Soy and Isoflavones. In The Role of Functional Food Security in Global Health. J. Nutr. Biochem.2019;22:379-394

6. Yang Y, Liu G, Zhang Y, Xu G, Yi X, Liang J,Yu M.Association Between Bone Mineral Density, Bone Turnover Markers, and Serum Cholesterol 
Levels in Type 2 Diabetes. Front.Endocrino. 2018;5:235-244.

7. Tareq M. Histological and Histomorphometrical Evaluation of local Application of Melatonin and BetaTricalcium Phosphate on Bone Healing in Rats .PhD thesis, College of Dentistry, Baghdad University,2018.

8. Jazayeri HE, Tahriri M, Razavi M, Khoshro O, Fahim F, Dashtim E, et al. A current overview of materials and strategies for potential use in maxillofacial tissue regeneration. Mater. Sci. Eng.2017;70:913-929.

9. Al-Ghaban N.Effects of glucocorticoiods- induced osteoporosis on osseointegration of titanium implants in rabbits (histological and histomorphometical study). PhD thesis, Collage of Dentistry, University of Baghdad,2008.

10. Radhi IH. Evaluation the Effect of Hyaluronic Acid on Healing Process of Intrabony Defect in Rabbits (Histomorphometrical and Immunohistochemical studies). MSc thesis, Collage of Dentistry, University of Baghdad, 2014.

11. Costa-pinto AR, Reis RL, Neves NM. Scaffolds based bone tissue engineering: the role of chitosan. Tissue Eng.2011;17(5):331-347.

12. Ramos GP, Apel MA, Morais CB, Ceolato PC, Schapoval EE, Dall'agnol M, et al. In vivo and in vitro anti-inflammatory activity of red clover Trifolium pratense dry extract. Rev. Bras. Farmacogn.2012;22(1):176-180.
13. Pilsakova L, Riecanský I, Jagla F. The physiological actions of isoflavone phytoestrogens.Physiol.Res.2010;59(5):651.

14. Belill KA, Settle TL, Angel CR, Kim SW, Rothwell SW. Femoral strength after induced lesions in rats (Rattus norvegicus).Comp.med. 2014;64(3):18.

15. Gautam AK, Bhargava NB, Tyagi AM, Srivastava K,Yadav DK, Kumar M, et al. Differential effects of formononetin and caldron on osteoblast function, peak bone mass achievement and bioavailability in rats. J.Nutr.Biochem. 2015;22(4):318-327.

16. Merolli A, Nicolais L, Ambrosio L, Santin MA. Degradable soybean-based biomaterial used effectively as a bone filler in vivo in a rabbit. Biomed Mater.2010;5(1):150-158.

17. Seeman E, Delmas PD. Bone quality-the material and structural basis of bone strength and fragility. N Engl J Me.2013;354(21):2250-2261

18. Occhiut F, Pasqueli RD, Guglielmo G, Palumbo D R, Zangla G, Samperi S, et al. Effects of phytoestrogenic isoflavones from red clover (Trifolium pratense L.) on experimental osteoporosis. Phytotherapy Research: An International Journal Devoted to Pharmacological and Toxicological Evaluation of Natural Product Derivatives. Nutr.2007;21(2):130-134.

19. Bharathi R, Baby D. Effect of phytoestrogen (isoflavones) rich soy food supplement on bone turnover among postmenopausal women. Int. J. Pharmacogn. Phytochem.2017;6(4):79-83.

الخلاصة - مانة

الهدف: إصلاح الأنسجة العظمية هي عمليه معقده متعددة الخطوات تشمل التضاعف التهاء , الهجرة الخلوية ,التفعيل والتعضية للعديد

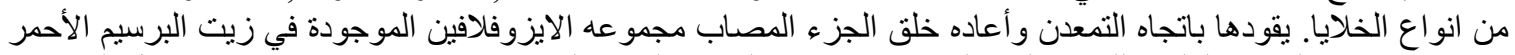

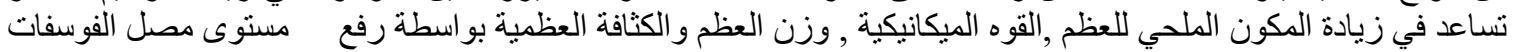
القاعدية.

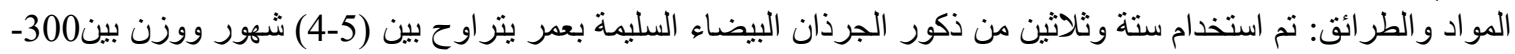

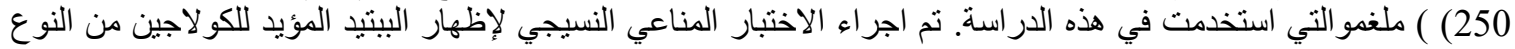

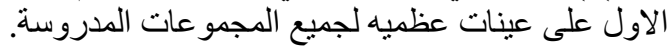
النتائج: اشـارت النتائج النسيجية التى ترسب التب العظم في الصفيحات العظمية التي تم در استها و التي شو هدت خلت خلال اسبو عين من تقدم

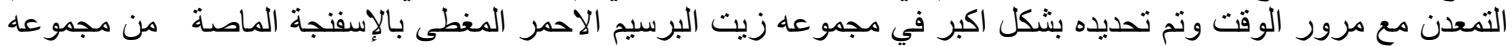

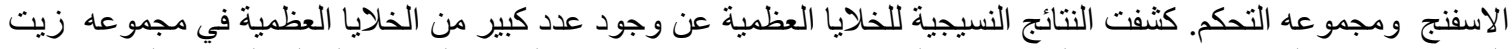
البرسيم الاحمر المغطى بالإسفنجة الماصة ) والتي التهي نتجت من إعداد اكبر من الخلايا العظمية المولدة لتكوين العظم مقارنها

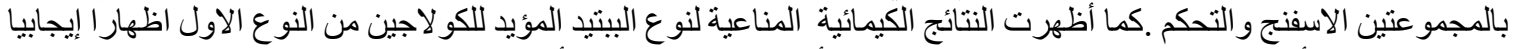

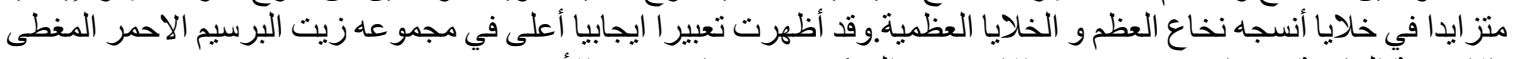

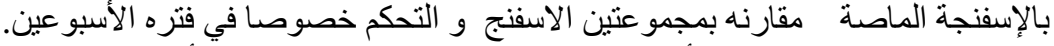

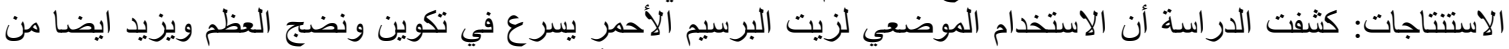
الاظهار الايجابي للبيتيد المؤيد للكو لاجين من النوع الاول في الخلل العظمي أكثر من العملية الفسيولوجية الطبيعية. 